\title{
Road Safety as a Public Health Problem: Case of Ecuador in the Period 2000-2019
}

\author{
Fabricio Esteban Espinoza-Molina ${ }^{1,2, *(0)}$, Christian Fernando Ojeda-Romero ${ }^{1}\left(\mathbb{C}\right.$, Henry David Zumba-Paucar ${ }^{1}(\mathbb{0}$, \\ Giovanny Pillajo-Quijia ${ }^{3}{ }^{-}$, Blanca Arenas-Ramírez ${ }^{2}{ }^{-1}$ and Francisco Aparicio-Izquierdo ${ }^{2}$ \\ 1 Transportation Engineering Research Group, Universidad Politécnica Salesiana (UPS), \\ Cuenca 010102, Ecuador; cojedar@est.ups.edu.ec (C.F.O.-R.); hzumbap@est.ups.edu.ec (H.D.Z.-P.) \\ 2 University Institute of Automobile Research Francisco Aparicio Izquierdo (INSIA), Universidad Politécnica \\ de Madrid (UPM), 28031 Madrid, Spain; blanca.arenas@upm.es (B.A.-R.); francisco.aparicio@upm.es (F.A.-I.) \\ 3 Escuela Técnica Superior de Ingeniería y Diseño Industrial (ETSIDI), Universidad Politécnica de \\ Madrid (UPM), 28012 Madrid, Spain; gp.pillajo@alumnos.upm.es \\ * Correspondence: fespinoza@ups.edu.ec
}

check for

updates

Citation: Espinoza-Molina, F.E.; Ojeda-Romero, C.F.; Zumba-Paucar, H.D.; Pillajo-Quijia, G.; ArenasRamírez, B.; Aparicio-Izquierdo, F. Road Safety as a Public Health Problem: Case of Ecuador in the Period 2000-2019. Sustainability 2021, 13, 8033. https://doi.org/10.3390/ su13148033

Academic Editor: Francisco Javier Camacho-Torregrosa

Received: 9 June 2021

Accepted: 11 July 2021

Published: 19 July 2021

Publisher's Note: MDPI stays neutral with regard to jurisdictional claims in published maps and institutional affiliations.

Copyright: (C) 2021 by the authors Licensee MDPI, Basel, Switzerland This article is an open access article distributed under the terms and conditions of the Creative Commons Attribution (CC BY) license (https:// creativecommons.org/licenses/by/ $4.0 /)$.

\begin{abstract}
Background: Road safety is a significant public health problem because it causes negative consequences on victims and families. The objective was to analyze the most significant changes in traffic crashes in Ecuador during the period from 2000 to 2019. With data obtained from the National Institute of Statistics and Census, we performed the analysis to identify: the number of traffic crashes, the number of victims, and other study variables. Methods: Descriptive and analytical statistics and the contrast of proportions were used to analyze data from 2000 to 2019. Results: According to the ideal joinpoint analysis model, there was a significant decrease in the number of recorded traffic accidents from 2015 to 2019 of -8.54 per year, while the tendency to die increased in females (2.05 per year) and males ( 3.29 per year). The most common crash was a collision, and the automobile appeared as the most involved vehicle from 2015 to 2019. The hypothesis test contrast is used to determine if statistically significant differences exist between age groups by gender of the driver injured in the period 2017-2018. Conclusions: This study determines the most significant changes in the variables related to traffic crashes, where mortality due to this cause in the last four years has had a growth rate of $1.8 \%$ compared to collisions that presented a rate of $-31.12 \%$. The contrast of the hypothesis test shows significant differences in the injury level between males and female drivers, depending on the age group.
\end{abstract}

Keywords: traffic crashes; fatality; causes of traffic crashes; types of traffic crashes; joinpoint; risk assessment

\section{Introduction}

Traffic accidents represent a problem that affects public health and road safety, giving rise to a mortality rate of 18.2 per 100,000 inhabitants worldwide, whereby the serious injuries generated by them are the eighth leading cause of death, causing 1.35 million deaths in 2016. They are currently the first cause of death in children and adolescents between 5 and 29 years old, generating $54 \%$ of deaths, which are vulnerable people such as pedestrians, cyclists, and motorcyclists. Ninety percent of deaths due to traffic accidents occur in low- and middle-income countries [1]. Therefore, the United Nations presented the Global Plan for the Decade of Action for Road Safety 2011-2020, where the goal is to halve the number of road traffic fatalities [2].

The Americas region shows an increasing trend in mortality due to traffic accidents [3]. In addition, Poswayo [4] states that traffic accidents are preventable, which means a reduction in the number of deaths and injuries. In 2016, deaths from this cause in this region cause $11 \%$ of deaths worldwide, with an average regional mortality rate of 15.6 per 100,000 inhabitants, and serious injuries represented the second leading cause of death in adolescents between 15 and 29 years of age. 
The Pan American Health Organization [3] indicates that traffic accidents in Ecuador are on the rise and consequently produce more fatalities, which is why the National Road Safety Plan of Ecuador establishes as a goal a 40\% decrease in deaths in the period 2015 to 2020 [5]; this means reducing the mortality rate from 19.47 in 2013 to 11.7 per 100,000 inhabitants by 2020 [6]. Furthermore, among the Sustainable Development Goals (SDGs), SDG 3.6 establishes reducing deaths by half. While SDG 11.2 mentions that everyone should have access to safe, affordable, accessible, sustainable transport systems and improved road safety by 2030 [2].

During the last three decades, Ecuador has had three traffic and road safety laws; approved on 10 April 1981, 2 August 1996, and 7 August 2008, respectively. The Organic Law of Land Transportation, Transit, and Road Safety of Ecuador (LOTTTSV) of 2008 was reformed on 29 March 2011, and at the end of 2014 again [7]. In addition, in 2016, the last reform of the enforcement regulations to the LOTTTSV was carried out; in it, essential changes were implemented such as the mandatory use of helmets for motorcycle drivers, recovery of driver's license points, having basic education certificate for non-professional licenses and high school diploma for professional licenses, a decrease in the level of alcohol allowed in the blood of drivers, and hardening of penalties $[7,8]$, in addition to the regulation and control of the sale of alcoholic beverages applied since 2010 [9]. Despite this, Ecuador, like many countries, did not achieve goal 3.6 (reduce fatalities by half) [10]; therefore, it signed the second Decade of Action for Road Safety 2021-2030 to address this problem of traffic accidents [11], generating a public health problem in Ecuador.

There is a lack of scientific studies conducted in Ecuador, on the significant changes in the statistics of the number of victims (injured and dead), demographic characteristics, vehicles involved, time of occurrence, causes, and types of traffic accidents in different period. In addition, there is a need for accurate data on deaths and injuries due to traffic crashes, to assess the real dimension of the problem or to evaluate the effectiveness of intervention measures, and it is a problem to be solved. Moreover, the underreporting of road traffic injuries has to be considered in Ecuador as it is in other countries. The research objective is to analyze the most significant changes in the number of road traffic accidents recorded in Ecuador from 2000 to 2019, considering variables in this study such as: number of victims, demographic characteristics, vehicles involved, causes, schedules, and types of crashes, through regression lines with tie points and the Monte Carlo method to identify substantial changes. In addition, statistically significant differences between male and female drivers, in terms of accident rates on Ecuadorian roads, are analyzed through the methodology of contrast of proportions, using data from 2017 and 2018.

This article is structured as follows: Section 2 reviews the state of the art, focusing on studies involving variables that describe traffic accidents. Section 3 explains the sources of information where the data used in the study are available, presents the variables used, and describes the methodology used. Section 4 shows the results and discussion. Finally, Section 5 presents the main conclusions of this study.

\section{State of the Art}

Some studies analyze traffic accident patterns [12], risk behaviors [13,14], causes of traffic accidents [9,15], types of traffic collisions [8], and time of occurrence [16]. They also determine that the severity of accidents depends on the vehicles involved $[17,18]$ and demographic characteristics [18-22]. In general, these investigations used historical data on traffic accidents and are descriptive. Several of them focus on recommendations to reduce the number of victims of traffic accidents and their consequences, such as the need to intervene to improve driver education for good driving behavior, improve vehicle safety, and provide better quality information for sound decision making.

Sex is an influential factor in road safety, as established in the literature [23-27].

Research on sex differences generally concludes that the crash rate or risk of being actively involved in a road traffic crash (especially fatal crashes) remains higher for 
men [24,25,27-31], although the crash rate for both sexes is influenced by age in the first place, with higher rates for young $[24,25,30,32,33]$ and older $[30,32]$ drivers.

The researchers agreed, males have a higher accident traffic rate because they are more involved "voluntarily" in risky behavior, mainly among younger drivers, which are more prone to "search of excitement" and are less experienced drivers [24,25,31-33]. The authors $[28,29,31,33]$ have concluded that males and young drivers are more likely to break the law. The study [34] concluded that females are easily distracted and incur more perception faults than males. In addition, other authors have stated that male's higher accident traffic rates are related to higher exposure [31-33]. However, exposure data are hard to collect and unreliable, and recourse to alternative methods such as indirect or quasiinduced exposure is necessary [25,32,35-38]. The investigation [39] driver collision patterns addressed by sex and age regarding offenses, collision type, and injury severity using clustering methodology and tests of proportions are used for a complimentary analysis when driver offense is present, concluding there are significant differences between males and females, showing that this tool is very useful to support conclusions.

The 2020 Jharkhand (Republic of India) study shows that $73.4 \%$ of males and $26.6 \%$ of females died from traffic crashes, with the majority being in the 21-30 age range [20]. Furthermore, in Ghana (Africa) in 2017, males are six times more likely to die from traffic crashes than females, with the highest incidence of fatalities in the age ranges of children and the elderly [21].

Previous studies carried out in Latin America have determined certain dangerous behaviors that affect road safety, among which are: exceeding speed limits, driving under the influence of alcohol, not wearing seat belts, or engaging in distracted driving [40,41]. In addition, there is research such as that carried out in Chile, which shows that the time of day when most traffic accidents occur is in the afternoon [16].

In a study conducted in Brazil [12], they determine that the rear-end collision is the most common type of traffic accident; furthermore, in another study in this country, in the state of Piauí, they analyze historical data from 2000 to 2017, where they define that the vehicle with the highest number of traffic accidents and responsible for almost half of the deaths was the motorcycle [18].

Traffic accidents represent a problem studied in different countries, which measure the impact and propose solutions according to the situation of each country. In the case of Ecuador, the Congacha study [42] determined that $96.3 \%$ of traffic accidents are explained by ten causes, with inattentive driving being the predominant one, with an incidence of $56.8 \%$, coinciding with other studies [9,15]. Another study conducted in Ecuador [43] states that the national statistics on traffic accidents collected by the responsible institutions have few variables which are not sufficiently disaggregated, and if they are available, not all of them are of good quality, which does not allow for more in-depth accident rate studies.

In Bhatti work [44], they state that underreporting exists in low-income countries, especially for light injuries [45], partly due to the lack of a well-structured data collection system $[46,47]$. This underreporting can be identified and avoided through police and hospital data reviews and software to standardize information [48], which is why it is essential to implement improvements in data collection in order to know the progress of road safety [49] and to allow comparison with other countries [50].

The National Traffic Agency (ANT) is the entity that keeps statistics on accidents and road accidents in the country. In recent years, it has categorized the probable causes of traffic accidents into 12 variables until 2013 and into 22 variables as of 2014 [51]. The variables collected in the official form of traffic accidents are in the following factors: (a) human factor, (b) vehicle factor, (c) environment factor, (d) to be defined, and (e) others, and it has not been possible to obtain from the official source, the concepts and cases encompassed in groups (d) and (e). From the exhaustive review carried out, two aspects stand out, namely the lack of and deficiency of information, on some crucial variables used to develop models that explain the causality of traffic accidents. The information collected at the accident site only allows general descriptive studies and obtaining the 
overall mortality rate (traffic accidents per total population) for comparative purposes between countries and regions of the world.

In line with the above, the International Transport Forum recommends that Ecuador build and sustain capacity and investment in road safety research and data systems. In particular, it recommends the following: radically improving the vehicle registration system and providing a more effective means of vehicle regulation, collecting traffic and travel data to help assess risk exposure and analyze road safety problems [52]. From a Vision Zero perspective, it requires the continued analysis of historical crash data systems that must be accessible, structured, and secure in the first place. Countries leading the way in road safety have done so through robust, continuous, and sophisticated information systems. They can better assess the risks of road traffic deaths and injuries, prioritize road safety interventions based on accurate data, and track their outcomes.

Therefore, the main objective of this work is to analyze the most significant changes in the number of traffic accidents registered in Ecuador from 2000 to 2019 and if there are differences from the statistical point of view, in the level of injury of drivers by gender and age groups, according to data availability in two years (2017-2018).

\section{Materials and Methods}

\subsection{Data Source}

The data for this study came from the National Institute of Statistics and Census, specifically from:

From the transport yearbooks published from the period 2000-2019 of traffic crashes, this base prepared by INEC with data from the National Traffic Agency, from which extracted information for the following variables: (a) the number of traffic accidents, (b) the number of victims, slightly injured and seriously injured (on-site severity), (c) causes of traffic accidents, (d) types of traffic accidents, (e) vehicle involved, and (f) time of traffic crashes; all these variables are collected on site $(24 \mathrm{~h})$.

The General Death Statistical Register provided data on fatalities from 2000 to 2019. From this database, the variables obtained were (a) number of deaths by traffic crashes, (b) sex, and (c) age; the latter recorded since 2008. According to INEC's methodology, data are collected monthly and published annually [53].

The data for inference and contrast of proportions between men and women drivers are prepared by INEC with data from the National Traffic Agency [53], where data on the severity of drivers according to sex and age groups are displayed in two years (2017-2018).

\subsection{Study Variables}

The information on the variables used in the study is shown in Table 1. It is limited to the variables available in the accessible data on traffic accidents in Ecuador.

Table 1. The variables used in the present study.

\begin{tabular}{|c|c|c|}
\hline Variable & Variable Type & Variable Implication \\
\hline $\begin{array}{c}\text { Causes of traffic } \\
\text { crashes }\end{array}$ & $\begin{array}{c}\text { Drunk driving } \\
\text { Lane drifting } \\
\text { Speeding } \\
\text { Driver recklessness } \\
\text { Pedestrian recklessness } \\
\text { Mechanical damage to the vehicle } \\
\text { Failure to obey traffic signs }\end{array}$ & $\begin{array}{l}\text { This variable is important because it helps to } \\
\text { determine the behavior of road users according to } \\
\text { categories. }\end{array}$ \\
\hline $\begin{array}{c}\text { Types of traffic } \\
\text { crashes }\end{array}$ & $\begin{array}{c}\text { Hit-and-run } \\
\text { Passenger drop } \\
\text { Collisions } \\
\text { Loss of track } \\
\text { Crashes } \\
\text { Friction inter vehicles } \\
\text { Overturn }\end{array}$ & $\begin{array}{l}\text { This variable identifies the most frequent types of } \\
\text { traffic accidents in Ecuador. There are types of } \\
\text { accidents with very harmful consequences for the } \\
\text { occupants and people involved in them. }\end{array}$ \\
\hline
\end{tabular}


Table 1. Cont.

\begin{tabular}{|c|c|c|}
\hline Variable & Variable Type & Variable Implication \\
\hline $\begin{array}{l}\text { Types of vehicles } \\
\text { involved in traffic } \\
\text { crashes }\end{array}$ & $\begin{array}{c}\text { Automobiles } \\
\text { Motorcycles } \\
\text { Pickup trucks } \\
\text { Sport utility vehicles (SUV) } \\
\text { Buses } \\
\text { Trucks }\end{array}$ & $\begin{array}{l}\text { Vehicle categories were considered as values for this } \\
\text { variable except bicycle (not collected), as the vehicle } \\
\text { type implies adequate road safety control. This } \\
\text { variable was collected from } 2015 \text { onwards. }\end{array}$ \\
\hline $\begin{array}{l}\text { Demographic } \\
\text { characteristics }\end{array}$ & $\begin{array}{l}\text { Sex } \\
\text { Age }\end{array}$ & $\begin{array}{l}\text { These two categories were considered in order to } \\
\text { obtain a more in-depth analysis of the victims } \\
\text { involved in traffic accidents. The age of the victim is } \\
\text { recorded from the year } 2008 \text { onwards. }\end{array}$ \\
\hline $\begin{array}{l}\text { Severity of traffic } \\
\text { crashes }\end{array}$ & $\begin{array}{c}\text { Fatalities (total per year) } \\
\text { On-site fatalities (recorded during } 24 \mathrm{~h} \text { ) } \\
\text { Minor injuries } \\
\text { Serious injuries (trauma that can result in disability } \\
\text { or death) }\end{array}$ & $\begin{array}{c}\text { This variable determines the consequence of traffic } \\
\text { accidents and helps to identify the severity of the } \\
\text { problem. The category of seriously injured is recorded } \\
\text { from } 2000 \text { to } 2013 \text { and from } 2014 \text { onwards, serious and } \\
\text { minor injuries are unified into a single } \\
\text { variable "injured". }\end{array}$ \\
\hline
\end{tabular}

\subsection{Study Method}

Descriptive statistics were performed, showing summarized information of the data, presenting averages. The relationship between demographic characteristics (sex) and onsite victims (deceased, seriously injured, and slightly injured) was analyzed from 2000 to 2013 using the chi-square test, because as of 2014, the entities in charge stopped collecting these variables and recorded them as a single variable (injured) without disaggregation.

The traffic crashes recorded evaluated by regression analysis using Joinpoint software (Joinpoint regression software version 4.8.0.1-April 2020, available from the US National Cancer Institute's Surveillance Research Program) [54]. The analysis performed in the software served to identify, through joinpoints, the most significant changes in the data entered, which helped identify the variables that are most relevant to the study, in addition to using the Monte Carlo permutation method present in the program to select the appropriate joinpoints by comparing two different joinpoints [55-57]. The Grid Search method was selected [58].

The program determined the Annual Percentage Change (APC), with a 95\% Confidence Interval (CI) for each analysis performed, which adjusted the regression by the natural logarithm of the rate, where the independent variable was the years of the period analyzed. In addition, the Provided Average Annual Percentage Change (AAPC) was obtained, which is a measure of the entire range of data. In the data of gender and age of the victims, an advanced analysis called Pairwise Comparison was performed, which had the purpose of seeing if the two regression mean functions were similar using the Parallel test, where a value of $p<0.05$ was statistically significant for the tests [59].

\subsection{The Contrast Proportions and Rates' Methodology}

This section evaluates the differences between male and female drivers in terms of severity of crashes that occurred in Ecuadorian roads from data encompassing the period 2017-2018. Starting from the general perception, according to which there are behavioral differences assigned in both groups toward traffic problems, such as those related to the levels of risk assumed and to the respect for traffic rules, which directly influence the number and types of road crashes and the injury level of drivers, it is necessary to make a risk comparison taking into account gender as well age. To this end, the exposure plays a fundamental role, but it is not available because the complexity and the cost to obtain directly. To face this problem, the methodology of contrast proportions is used for the analysis of statistically significant differences in the severity of male and female drivers, according to age intervals, as the available and disaggregated data allow it (2017-2018). 


\subsection{Statistically Significant Differences between Males and Females Drivers Injured in Crashes}

For statistically significant differences determination between male and female drivers involved in road crashes, regarding the harmfulness by age group, we have applied proportions and rates' contrast methodology.

The test of proportions tries to analyze whether the sample data allow rejecting the hypothesis of equality of proportions of a determined characteristic of two populations or, on the contrary, the differences between the proportions of the sample, obtained from the data, are too much to accept it or, in statistical terminology, not to reject it.

The statistic, i.e., the function of the data applied in this case, is the difference between the proportions divided by an estimate of the standard deviation of this difference:

$$
d=\frac{\overline{P_{1}}-\overline{P_{2}}}{\sqrt{\frac{\bar{P}_{1}}{n_{1}}}+\overline{P_{2}}}
$$

The above equation, under the null hypothesis of equality of population proportions, is distributed approximately as a standard Gaussian; thus, when $(d)$ takes values in the tails of the distribution, typically outside the interval $(-2,2)$, the hypothesis must be rejected, since the behavior of the samples is peripheral or inconsistent with what is expected if equality of proportions were to hold.

\section{Results and Discussion}

\subsection{Data Descriptive and Regression Analysis by Joinpoint Results}

The total number of traffic accidents and injury victims (fatalities and slightly and seriously injured), a ratio per 100,000 inhabitants, and their variations in the period 20002019 are presented in Table 2.

Table 2. Number of traffic crashes and fatalities recorded on site from 2000-2019 in Ecuador.

\begin{tabular}{|c|c|c|c|c|c|c|c|c|c|c|}
\hline Year & $\begin{array}{c}\text { Number } \\
\text { of Road } \\
\text { Traffic } \\
\text { Crashes }\end{array}$ & $\begin{array}{c}\text { Total } \\
\text { Number } \\
\text { of Casual- } \\
\text { ties }\end{array}$ & $\begin{array}{c}\text { Casualty } \\
\text { Rate per } \\
100,000\end{array}$ & $\begin{array}{l}\text { Difference of } \\
\text { Victims per } \\
100,000 \\
\text { Inhabitants }\end{array}$ & $\begin{array}{l}\text { Deceased } \\
\text { on Site }\end{array}$ & $\begin{array}{c}\text { On-Site } \\
\text { Fatalities per } \\
100,000 \\
\text { Inhabitants }\end{array}$ & $\begin{array}{l}\text { Difference in } \\
\text { Deaths on } \\
\text { Site per } \\
100,000 \\
\text { Inhabitants }\end{array}$ & Injury & $\begin{array}{c}\text { Light } \\
\text { Injury }\end{array}$ & $\begin{array}{c}\text { Serious } \\
\text { Injury }\end{array}$ \\
\hline 2000 & 15,987 & 7710 & 61.5 & & 1099 & 8.8 & & 6611 & 5837 & 774 \\
\hline 2001 & 11,008 & 4986 & 38.9 & -36.8 & 816 & 6.4 & -27.4 & 4170 & 4058 & 112 \\
\hline 2002 & 12,215 & 6357 & 48.5 & 24.8 & 1038 & 7.9 & 24.5 & 5319 & 5236 & 83 \\
\hline 2003 & 10,369 & 6841 & 51.4 & 5.8 & 1139 & 8.6 & 7.9 & 5702 & 5615 & 87 \\
\hline 2004 & 16,323 & 10,128 & 74.7 & 45.5 & 1273 & 9.4 & 9.9 & 8855 & 8677 & 178 \\
\hline 2005 & 16,578 & 10,697 & 78.0 & 4.3 & 1387 & 10.1 & 7.6 & 9310 & 9098 & 212 \\
\hline 2006 & 18,572 & 11,312 & 81.0 & 3.9 & 1801 & 12.9 & 27.6 & 9511 & 9082 & 429 \\
\hline 2007 & 19,598 & 13,882 & 97.7 & 20.6 & 1848 & 13.0 & 0.8 & 12,034 & 11,629 & 405 \\
\hline 2008 & 19,664 & 12,627 & 87.2 & -10.7 & 1343 & 9.3 & -28.6 & 11,284 & 11,108 & 176 \\
\hline 2009 & 21,528 & 17,032 & 115.6 & 32.5 & 1998 & 13.6 & 46.1 & 15,034 & 14,847 & 187 \\
\hline 2010 & 25,588 & 22,485 & 149.8 & 29.6 & 2313 & 15.4 & 13.7 & 20,172 & 19,862 & 310 \\
\hline 2011 & 24,625 & 21,211 & 138.9 & -7.2 & 2049 & 13.4 & -12.9 & 19,162 & 18,939 & 223 \\
\hline 2012 & 23,854 & 20,524 & 132.2 & -4.8 & 2242 & 14.4 & 7.6 & 18,282 & 18,210 & 72 \\
\hline 2013 & 28,169 & 24,928 & 158.0 & 19.5 & 2277 & 14.4 & -0.1 & 22,651 & 22,573 & 78 \\
\hline 2014 & 38,658 & 29,990 & 187.1 & 18.4 & 2322 & 14.5 & 0.4 & 27,668 & \multirow{6}{*}{\multicolumn{2}{|c|}{$\mathrm{n} / \mathrm{a}^{1}$}} \\
\hline 2015 & 35,706 & 27,372 & 168.1 & -10.1 & 2138 & 13.1 & -9.3 & 25,234 & & \\
\hline 2016 & 30,269 & 23,425 & 141.7 & -15.7 & 1967 & 11.9 & -9.4 & 21,458 & & \\
\hline 2017 & 28,967 & 24,171 & 144.1 & 1.7 & 2153 & 12.8 & 7.8 & 22,018 & & \\
\hline 2018 & 25,530 & 22,009 & 129.3 & -10.3 & 2151 & 12.6 & -1.5 & 19,858 & & \\
\hline 2019 & 24,595 & 22,179 & 130.1 & 0.6 & 2180 & 12.8 & 1.2 & 19,999 & & \\
\hline
\end{tabular}

Note: ${ }^{1}$ There was no injury classification in recent years.

From 2000 to 2019, there were 447,803 traffic accidents in Ecuador, with a balance of 304,332 injured and 35,534 deaths on the spot. The most significant reduction concerning the previous year in traffic accidents occurred in 2001, with a decrease of $36.8 \%$ in the rate of victims per 100,000 inhabitants. The figures may have been due to the economic problems and political instability of the country in 2000 [60]. In addition, before the dollarization of 
the economy (the year 2000), the country had a stagnant gross domestic product growth rate of $1.8 \%$ per year. In the following years, GDP averaged $4.4 \%$ [61], and this growth may have contributed to the increase in traffic accidents $[62,63]$.

Within the period analyzed, the highest number of traffic accidents occurred in the year 2014 with $8.63 \%$ of the total number of accidents, while the lowest was in the year 2003 with a $2.31 \%$. This figure could be due to the change in the Regulation to the Law of Ground Transportation, Transit, and Road Safety, which entered in January of that same year, where it reinforced the curricula for non-professional driver training schools and also modified the maximum blood alcohol limit allowed for driving $(0.8 \mathrm{~g} / \mathrm{L})$ [8].

The analysis of the database of the National Traffic Agency from 2000 to 2019 reveals the absence of some variables such as data of road users (pedestrian, passenger, and driver), type of driving license, type of road, road conditions or weather conditions, vehicle damage, type and age of vehicle, and, in some years, it lacks the number of serious and minor injuries, age and sex of the victims, which ostensibly limits the possibility of the scientific study of traffic accidents with a greater level of depth. The crash data collection system needs to be improved and that it is essential to carry out studies to broaden the knowledge of road safety in Ecuador. Tools and resources for this purpose are appearing every day and require exhaustive, continuous, rigorous, and complete information systems. The variations in criteria over time make it practically impossible to carry out rigorous studies on the evolution of accident conditions and to evaluate the effects of measures for improvement [64]. The definition of policies and measures requires more and better knowledge extracted from the data.

About the previous paragraphs, traffic accident data for Ecuador from 2000 to 2019 were analyzed. Regression analysis using Joinpoint software helps to identify the most significant changes in the period. See Figure 1.

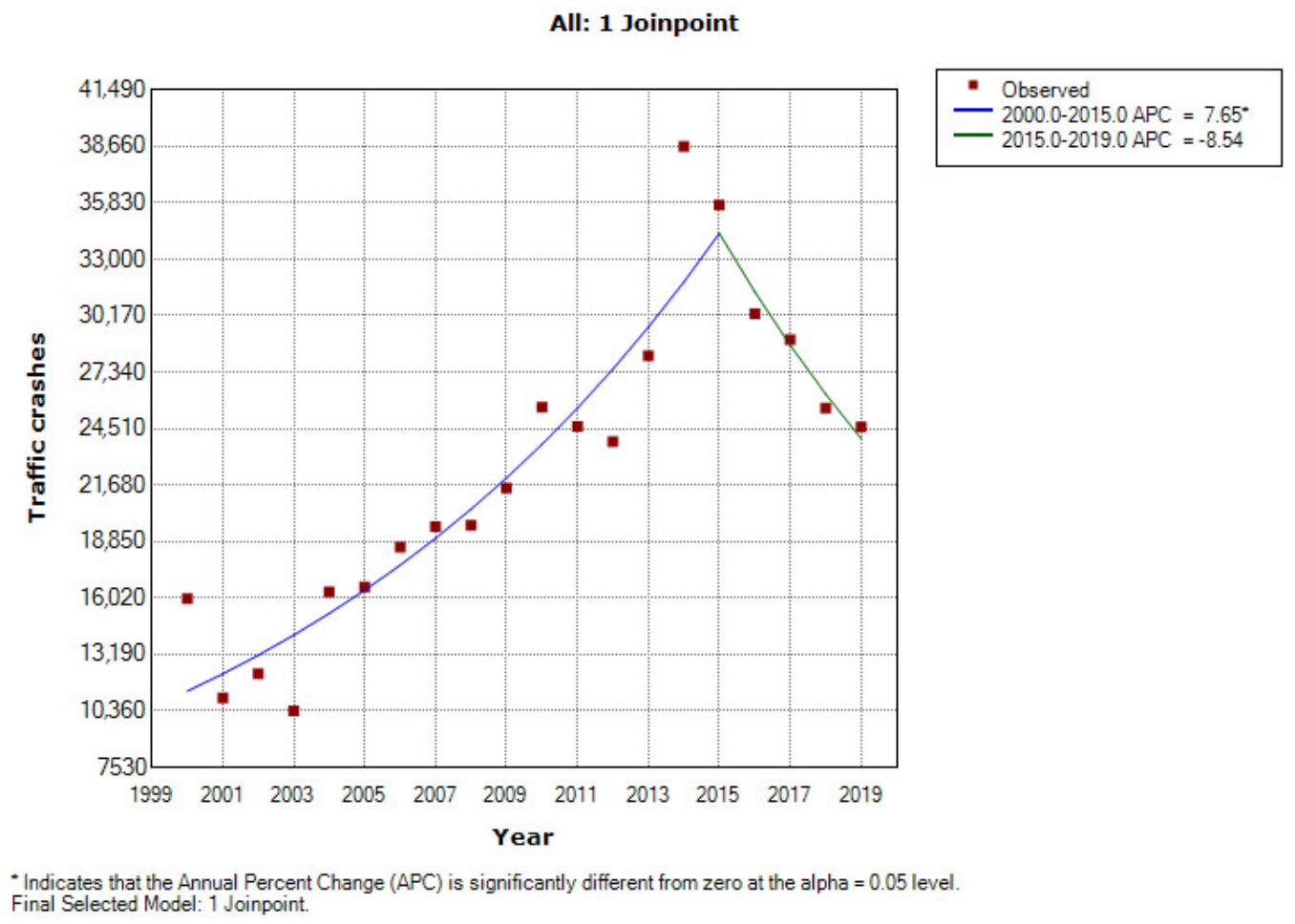

Figure 1. Analysis of traffic crashes joinpoints in Ecuador.

From Figure 1, the junction point in 2015 ( $p=0.0022)$ stands out, demonstrating the most significant change in traffic accidents. In the period from 2000 to 2015, traffic accidents increased significantly by 7.65 per year (95\% CI: 5.7 to 9.6$)$, representing $75.58 \%$ of traffic accidents, which probably may be due to the average increase of $8.08 \%$ of the vehicle fleet 
in Ecuador in those years $[65,66]$, non-compliance with traffic law, vehicles with little or no safety equipment. As of 2016, they decreased by -8.54 per year ( $95 \%$ CI: -20.2 to 4.9 ), with $24.2 \%$ of the total number of traffic accidents; this decrease can probably be attributed has the reform of the land transport law regulation [67], in addition to the investment in road improvement, construction, and reconstruction [68], since these types of investments positively affect traffic accidents according to Calvo-Poyo study [69]. Likewise, the increase in breathalyzer tests for drivers and the implementation of computerized radars [70] have been part of the state surveillance program, which was demonstrated as a very effective measure to improve road safety in other countries.

Table 3 shows the types of vehicles involved in traffic accidents from 2015 to 2019 in Ecuador. Before 2015, this variable was not in the records. It is the type of vehicle against which people are impacted or occupied at the time of the accident, which is of utmost importance in crashworthiness and severity studies.

Table 3. The number of vehicles involved in traffic crashes in Ecuador from 2015 to 2019.

\begin{tabular}{ccccccccc}
\hline Year & Automobile & Motorcycle & Pickup & SUV & Bus & Truck & Other & Unidentified \\
\hline 2015 & 21,521 & 9107 & 7525 & 5342 & 3436 & 2370 & 3992 & $\mathrm{n} / \mathrm{a}^{1}$ \\
2016 & 16,105 & 8072 & 5829 & 3851 & 2611 & 2292 & 2936 & $\mathrm{n} / \mathrm{a}^{1}$ \\
2017 & 16,146 & 7533 & 5446 & 4151 & 2506 & 2360 & 2138 & 3517 \\
2018 & 15,337 & 6653 & 4490 & 1842 & 1599 & 2428 & 945 & 21,834 \\
2019 & 14,270 & 7256 & 4120 & 1893 & 1693 & 2367 & 948 & 6849 \\
\hline
\end{tabular}

Note: ${ }^{1}$ Data not available in the ANT database.

From Table 3, the automobile participated in the highest number of traffic accidents with $35.74 \%$, and the one with the lowest involvement was the truck with $4.70 \%$. In addition, in the Joinpoint analysis, most of the vehicles involved in traffic accidents presented a decrease per year; automobile (-8.3), motorcycle (-6.3), pickup truck (-13.6), SUV (-24.5), bus $(-17.4)$, and truck type was the only one that increased +0.6 per year.

In the work of Pillajo-Quijia [71], they apply machine-learning methods to explain the severity of driver injuries in hit-and-run accidents involving light commercial vehicles, such as vans and pickup trucks, and vehicle types are one of the influential factors.

The study conducted in the state of Piauí (Brazil) indicates that the motorcycle produced the highest number of deaths [18], while in Ecuador between 2015 and 2019 did not present any similarity; however, this may change in the future and will motivate studies. It is worth mentioning that in Ecuador, the growth rate of motorcycle sales between 2018 and 2019 was $12.31 \%$, while the sales of automobiles decreased by $7.9 \%$ [72].

Table 4 shows the causes that have generated traffic accidents in the period 2000-2019 in Ecuador.

Table 4 shows that driver recklessness and carelessness is the predominant cause (representing 41.76\%). Furthermore, the Joinpoint analysis indicates that from 2000 to 2013, this cause increased annually by 12.97 (95\% CI: from 10.3 to 15.6), and since 2014, it decreased by -2.61 (95\% CI: from -9.7 to 5.0 ). This result is similar to that obtained in previous studies from Ecuador [15,42]: the predominant cause is driver recklessness and carelessness, followed by speeding. A study conducted in Colombia on traffic fatalities also found that the causes with the highest fatality rate were reckless driving and speeding [41], and more examples can be found around the world.

The other causes did not show a decreasing trend over the years: disrespect of traffic signs (representing $9.49 \%$ of the causes of traffic accidents), invasion of oncoming traffic lanes with $9.07 \%$, and speeding with $14.19 \%$. The state of these results should motivate the monitoring and surveillance of compliance with the rules by the authorities in the field. Excessive speed is one of the principal causes of fatalities and minor injuries in traffic accidents, of which the WHO [1] points out that no corrective measures have been taken. There is sufficient evidence and agreement that an average $5 \%$ reduction in speed can lead to a $20 \%$ reduction in the number of fatal traffic accidents [5,73]. 
Table 4. Causes of traffic crash in Ecuador in the period 2000-2019.

\begin{tabular}{|c|c|c|c|c|c|c|c|c|}
\hline Year & $\begin{array}{l}\text { Drunkenness } \\
\text { or Drug }\end{array}$ & $\begin{array}{c}\text { Lane } \\
\text { Encroachment }\end{array}$ & $\begin{array}{l}\text { Excessive } \\
\text { Speed }\end{array}$ & $\begin{array}{c}\text { Driver } \\
\text { Recklessness }\end{array}$ & $\begin{array}{c}\text { Pedestrian } \\
\text { Recklessness }\end{array}$ & $\begin{array}{l}\text { Mechanical } \\
\text { Damage }\end{array}$ & $\begin{array}{l}\text { Disrespecting } \\
\text { Traffic Signals }\end{array}$ & Other \\
\hline 2000 & 1804 & 1941 & 2646 & 3807 & 902 & 630 & 1061 & 3196 \\
\hline 2001 & 1430 & 1893 & 1381 & 2842 & 851 & 502 & 885 & 1224 \\
\hline 2002 & 1354 & 1845 & 1503 & 3739 & 870 & 408 & 709 & 1787 \\
\hline 2003 & 1120 & 1265 & 1846 & 3619 & 798 & 243 & 175 & 1303 \\
\hline 2004 & 1724 & 1983 & 2764 & 5739 & 1073 & 386 & 1237 & 1417 \\
\hline 2005 & 1765 & 1998 & 2865 & 6080 & 1232 & 423 & 1018 & 1197 \\
\hline 2006 & 1829 & 2458 & 3394 & 6192 & 1351 & 405 & 1163 & 1780 \\
\hline 2007 & 1770 & 2613 & 4142 & 6561 & 1298 & 443 & 1419 & 1352 \\
\hline 2008 & 1605 & 2200 & 3149 & 6728 & 1279 & 246 & 893 & 3564 \\
\hline 2009 & 2172 & 2200 & 4615 & 8313 & 1366 & 371 & 1247 & 1244 \\
\hline 2010 & 2633 & 1640 & 3685 & 13,548 & 1251 & 346 & 856 & 1629 \\
\hline 2011 & 2484 & 964 & 3517 & 12,469 & 2004 & 398 & 1514 & 1275 \\
\hline 2012 & 2001 & 1711 & 2112 & 12,504 & 1788 & 365 & 1197 & 2176 \\
\hline 2013 & 2251 & 398 & 2292 & 14,662 & 2005 & 373 & 2224 & 3964 \\
\hline 2014 & 2438 & 3001 & 3892 & 13,835 & 2075 & 393 & 8027 & 4997 \\
\hline 2015 & 2400 & 4101 & 3777 & 11,965 & 1598 & 338 & 5244 & 6283 \\
\hline 2016 & 2096 & 2526 & 3755 & 15,709 & 1241 & 229 & 3796 & 917 \\
\hline 2017 & 2094 & 2616 & 4147 & 13,818 & 1442 & 188 & 3993 & 669 \\
\hline 2018 & 1913 & 1584 & 4068 & 12,660 & 1155 & 284 & 3046 & 820 \\
\hline 2019 & 1755 & 1678 & 4006 & 12,234 & 1317 & 170 & 2772 & 663 \\
\hline
\end{tabular}

According to the Regulation to the Law of Ground Transportation, Transit, and Road Safety in force since 2016 in Ecuador, they modified the speed limits according to the type of public road $(50 \mathrm{~km} / \mathrm{h}$ in urban areas, $90 \mathrm{~km} / \mathrm{h}$ in perimeters, $100 \mathrm{~km} / \mathrm{h}$ in straights, $135 \mathrm{~km} / \mathrm{h}$ in highways, and $60 \mathrm{~km} / \mathrm{h}$ in curves) and school zones reduced from 35 to $20 \mathrm{~km} / \mathrm{h}$ [67], compared to the 2009 Regulation, where they set three types of speed limits [74]. With these types of updates, Ecuador demonstrates that it has taken actions in speed enforcement, which can be associated with the decrease in traffic accidents as of 2016. In addition, this may be due to drivers' behaviors and the training they receive, as they do not respect speed limits and traffic signs [75].

Table 5 shows the timetable of occurrence of traffic accidents in Ecuador from 2015 to 2019.

Table 5. Traffic crashes according to the hour range in which they occurred during the period 2015-2019.

\begin{tabular}{ccccc}
\hline Year & $\mathbf{0 : 0 0 - 5 : 5 9}$ & $\mathbf{6 : 0 0 - 1 1 : 5 9}$ & $\mathbf{1 2 : 0 0 - 1 7 : 5 9}$ & $\mathbf{1 8 : 0 0 - 2 3 : 5 9}$ \\
\hline 2015 & 5308 & 9729 & 11,068 & 9601 \\
2016 & 4666 & 8106 & 9175 & 8322 \\
2017 & 4706 & 7565 & 8578 & 8118 \\
2018 & 4654 & 6356 & 7416 & 7104 \\
2019 & 4671 & 6144 & 6915 & 6865 \\
\hline
\end{tabular}

The highest number of traffic accidents occurred between 12:00 am and 5:59 pm with $29.75 \%$, coinciding with the study conducted in Chile [16], followed by $6: 00 \mathrm{pm}$ to $11: 59 \mathrm{pm}$ with $27.58 \%$. The number of traffic accidents during the early morning hours was lower $(16.55 \%)$ in Ecuador, which was a discrepancy with the study conducted in Cartagena (Colombia), where the highest number of traffic accidents occurred during the early morning hours [76].

The Joinpoint analysis showed a decreasing trend in traffic collisions during the following hours: from 0:00 to 5:59 h -2. 55 (95\% CI: from -7.0 to 2.7), from 6: 00 to 11: $59 \mathrm{~h}$ by -10.97 ( $95 \%$ CI: from -14.8 to -7.0$)$, from 12 : 00 to 17 : $59 \mathrm{~h}$ by -19.90 ( $95 \% \mathrm{CI}$ : from -14.0 to -7.7$)$, and from 18: 00 to 28 : $59 \mathrm{~h}$ by -7.96 per year ( $95 \%$ CI: from -4.7 to -7.6 ).

Figure 2 shows the changes in traffic accidents between two time slots in Ecuador from 2015 to 2019. 
0:00 to 11:59 hours (am): 0 Joinpoints versus 12:00 to 23:59 hours (pm): 0 Joinpoints
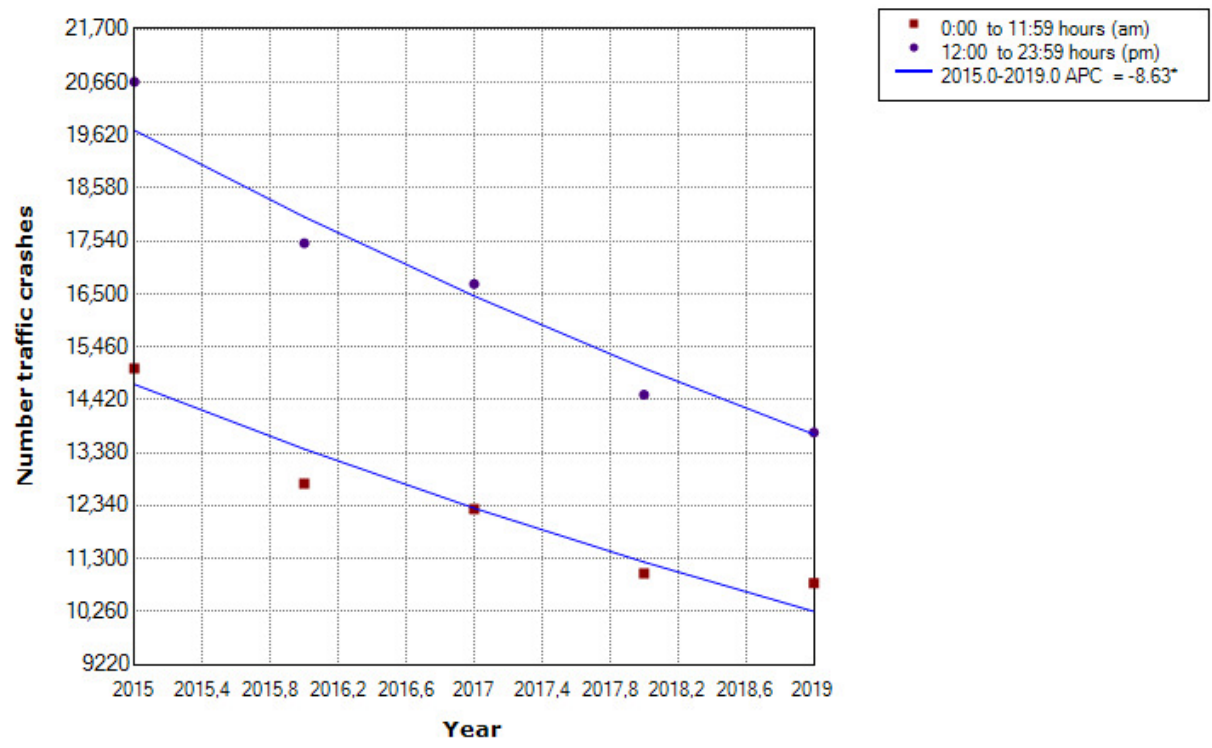

- Indicates that the Annual Percent Change (APC) is significantly different from zero at the alpha $=0.05$ level.
Final Selected Model: 0:00 to 11:59 hours (am) - 0 Joinpoints, 12:00 to $23: 59$ hours ( $\mathrm{pm}$ ) - 0 Joinpoints. Failed to reject Parallelism.

Figure 2. Comparison analysis of the schedules in which traffic crashes occurred in Ecuador, in the period 2015-2019.

The comparison of traffic crashes between the morning (0:00 to 11:59 $\mathrm{h}$ ) and the afternoon (12:00 to 23:59 h) showed that the decrease in traffic crashes between the two schedules was parallel $(p=0.10)$ with a total reduction of -8.63 per year as shown in Figure 2.

Table 5 shows the number of fatalities by gender recorded in $24 \mathrm{~h}$ from 2000 to 2013.

In Ecuador, the number of males with light and serious injuries was double that of females between 2000 and 2013, as shown in Table 6. The chi-square analysis of the relationship between the variables of sex of the victims involved in traffic accidents and injury severity shows that the variables are independent, as concluded by other studies [23-27,59]. A recent work concerning gender in road safety has applied clustering analysis to the pattern identification in road crashes with two passenger cars in Spain [39].

Table 6. Number of victims of traffic crashes by gender in Ecuador in the period 2000-2019 (24 h on site).

\begin{tabular}{cccccccc}
\hline \multirow{2}{*}{ Year } & \multicolumn{2}{c}{ Deceased on Site } & \multicolumn{2}{c}{ Lightless Injured } & \multicolumn{2}{c}{ Severely Injured } & \multirow{2}{*}{$\boldsymbol{p}$} \\
\cline { 2 - 6 } & Female & Male & Female & Male & Female & Male & \\
\hline 2000 & 236 & 863 & 1994 & 3843 & 272 & 502 & \\
2001 & 175 & 641 & 1371 & 2687 & 27 & 85 & \\
2002 & 281 & 757 & 1718 & 3518 & 24 & 59 & \\
2003 & 263 & 876 & 1845 & 3770 & 31 & 56 & \\
2004 & 288 & 985 & 2847 & 5830 & 57 & 121 & \\
2005 & 359 & 1028 & 3158 & 5940 & 60 & 152 & \\
2006 & 464 & 1337 & 2898 & 6184 & 144 & 285 & \multirow{2}{*}{0.05} \\
2007 & 543 & 1305 & 3780 & 7849 & 130 & 275 & \\
2008 & 264 & 1079 & 3572 & 7536 & 40 & 136 & \\
2009 & 483 & 1515 & 5057 & 9790 & 71 & 116 & \\
2010 & 460 & 1853 & 6548 & 13,314 & 116 & 194 & \\
2011 & 399 & 1650 & 6391 & 12,548 & 87 & 136 & \\
2012 & 470 & 1772 & 5982 & 12,228 & 26 & 46 & \\
2013 & 463 & 1814 & 7368 & 15,205 & 33 & 45 & \\
\hline
\end{tabular}

Table 7 shows the types of traffic accidents recorded in the period 2000-2019 in Ecuador. 
Table 7. Types of the traffic crash recorded in Ecuador from 2000 to 2019.

\begin{tabular}{|c|c|c|c|c|c|c|c|c|}
\hline Year & $\begin{array}{l}\text { Hit-and- } \\
\text { Run }\end{array}$ & $\begin{array}{c}\text { Passenger } \\
\text { Drop }\end{array}$ & Collision & $\begin{array}{c}\text { Loss of } \\
\text { Track }\end{array}$ & Crash & $\begin{array}{c}\text { Friction Inter } \\
\text { Vehicles }\end{array}$ & Overturn & Other \\
\hline 2000 & 2680 & 239 & 7801 & 225 & 2278 & 1543 & 785 & 436 \\
\hline 2001 & 1912 & 93 & 5206 & 119 & 1780 & 774 & 719 & 405 \\
\hline 2002 & 1933 & 82 & 5699 & 107 & 1984 & 1188 & 806 & 416 \\
\hline 2003 & 1908 & 89 & 4424 & 133 & 1752 & 1001 & 796 & 266 \\
\hline 2004 & 3165 & 237 & 7228 & 339 & 2698 & 1521 & 1026 & 109 \\
\hline 2005 & 3133 & 288 & 7192 & 390 & 2755 & 1538 & 1113 & 169 \\
\hline 2006 & 3641 & 342 & 8059 & 455 & 3061 & 1633 & 1184 & 197 \\
\hline 2007 & 3595 & 277 & 8530 & 499 & 3424 & 1737 & 1137 & 399 \\
\hline 2008 & 3475 & 217 & 8398 & 359 & 3161 & 1408 & 1153 & 1493 \\
\hline 2009 & 4171 & 431 & 9397 & 693 & 3516 & 1425 & 1272 & 623 \\
\hline 2010 & 4581 & 480 & 12,025 & 795 & 3898 & 1699 & 1288 & 822 \\
\hline 2011 & 4505 & 434 & 11,632 & 1143 & 3900 & 1751 & 1104 & 156 \\
\hline 2012 & 4147 & 488 & 10,936 & 1270 & 3602 & 1636 & 1088 & 687 \\
\hline 2013 & 4769 & 564 & 13,145 & 1370 & 3811 & 1769 & 1103 & 1638 \\
\hline 2014 & 6476 & 750 & 18,412 & 2545 & 4825 & 2735 & 1455 & 1460 \\
\hline 2015 & 5431 & 810 & 17,137 & 3471 & 4624 & 2597 & 1054 & 582 \\
\hline 2016 & 5075 & 834 & 13,745 & 3273 & 4017 & 2051 & 763 & 511 \\
\hline 2017 & 4958 & 865 & 13,197 & 3501 & 3647 & 1813 & 617 & 369 \\
\hline 2018 & 4288 & 762 & 11,629 & 2977 & 3417 & 1213 & 540 & 704 \\
\hline 2019 & 3992 & 705 & 11,372 & 3064 & 3234 & 1248 & 416 & 564 \\
\hline
\end{tabular}

The lowest number of traffic accidents was for passenger drops with $2 \%$, and the highest was collisions, with an average of $45.29 \%$. The Joinpoint analysis determined that passenger drops from 2005 to 2009 increased by 9.04 (95\% CI: from 5.8 to 12.4) per year, and collisions from 2014 to 2019 decreased by -6.28 (95\% CI: from -13.1 to 1.1). Both types of crashes should be trend-tracked. Pedestrian crashes are also significant in number; moreover, other vulnerable road users should be studied in dedicated works.

Collision is one of the most frequent configurations, and the severity changes according to the type of collision. Head-on collisions are the most injurious compared to rear-end collisions, and being the predominant accident type in Ecuador, there was no categorization until 2013. In the last years, a side collision represented $58.49 \%$, followed by rear collision at $21.53 \%$, frontal collision at $13.81 \%$, and other collisions at $6.18 \%$. Research conducted in Colombia shows that collisions between vehicles are the fourth leading cause of death [77]. In the study conducted in Brazil [12], rear-end collisions are the leading cause of traffic accidents.

Table 8 shows the variation of annual deaths concerning those registered in $24 \mathrm{~h}$ in the period 2000-2019 caused by traffic accidents and the ratio of deaths per 100,000 inhabitants in Ecuador.

The growth rate of the number of fatalities (annual) was 1.8\% from 2015 to 2019 . Table 8 shows that the number of males who die in traffic accidents is higher than that of females; approximately six males and two females die per day in traffic accidents in Ecuador. Other research $[20,21]$ shows that sex is a factor that influences traffic accidents in several countries $[23,26,27]$.

The average rate of deaths per 100,000 inhabitants is 18.2 in Ecuador between 2000 and 2019; the result obtained is close to those recorded in 2016 by countries in Latin America and the Caribbean, highlighting the worrying situation for several countries such as El Salvador, Paraguay, Guyana, and Belize with a rate value around 20 with a rate value around 20 deaths per 100,000 inhabitants [78]. If we compare this with the European region, which had a rate of 9.3 deaths per 100,000 inhabitants [79] in the same year, the dimension of the health problem to be faced in Ecuador becomes evident.

When comparing the annual death data between INEC and those recorded in situ (24 h) by ANT, there was an average variation of $35.97 \%$ between 2000 and 2019 . This finding is very similar to that of other countries [43,45,48]. According to Furas's study, underreporting in Latin America varies from 12\% in Colombia to 29\% in Ecuador [80]. The situation is also affected by the lack of disaggregated variables in Ecuador, highlighting 
the need for a well-structured data collection system, as recommended by international institutions for Ecuador [1,52].

Table 8. The variation between the recorded data of deaths on site ( $24 \mathrm{~h}$ ) and deaths (annual) from 2000 to 2019.

\begin{tabular}{|c|c|c|c|c|c|c|c|}
\hline Year & $\mathbf{a}$ & $\begin{array}{l}\text { Deceased } \\
\text { Male }\end{array}$ & Total Deaths & $\begin{array}{l}\text { Deceases } \\
(24 \mathrm{~h})^{1}\end{array}$ & $\begin{array}{l}\text { Variation } \\
(\%)\end{array}$ & $\begin{array}{l}\text { Deaths per 100,000 } \\
\text { Inhabitants }\end{array}$ & $\begin{array}{l}\text { Difference in Deaths } \\
\text { per } 100,000 \text { Inhabitants }\end{array}$ \\
\hline 2000 & 444 & 1597 & 2041 & 1099 & 46.15 & 16.29 & \\
\hline 2001 & 434 & 1465 & 1899 & 816 & 57.03 & 14.82 & -9.02 \\
\hline 2002 & 436 & 1523 & 1959 & 1038 & 47.01 & 14.96 & 0.96 \\
\hline 2003 & 442 & 1568 & 2010 & 1139 & 43.33 & 15.09 & 0.86 \\
\hline 2004 & 416 & 1427 & 1843 & 1273 & 30.93 & 13.60 & -9.88 \\
\hline 2005 & 514 & 1865 & 2379 & 1387 & 41.70 & 17.34 & 27.49 \\
\hline 2006 & 546 & 1974 & 2520 & 1801 & 28.53 & 18.05 & 4.08 \\
\hline 2007 & 524 & 2131 & 2655 & 1848 & 30.40 & 18.68 & 3.50 \\
\hline 2008 & 503 & 2188 & 2691 & 1343 & 50.09 & 18.59 & -0.45 \\
\hline 2009 & 641 & 2535 & 3176 & 1998 & 37.09 & 21.55 & 15.90 \\
\hline 2010 & 660 & 2644 & 3304 & 2313 & 29.99 & 22.01 & 2.13 \\
\hline 2011 & 615 & 2736 & 3351 & 2049 & 38.85 & 21.95 & -0.26 \\
\hline 2012 & 655 & 2521 & 3176 & 2242 & 29.41 & 20.46 & -6.78 \\
\hline 2013 & 614 & 2532 & 3146 & 2277 & 27.62 & 19.94 & -2.54 \\
\hline 2014 & 626 & 2475 & 3101 & 2322 & 25.12 & 19.35 & -2.98 \\
\hline 2015 & 586 & 2537 & 3123 & 2138 & 31.54 & 19.18 & -0.85 \\
\hline 2016 & 574 & 2364 & 2938 & 1967 & 33.05 & 17.77 & -7.35 \\
\hline 2017 & 598 & 2419 & 3017 & 2153 & 28.64 & 17.98 & 1.17 \\
\hline 2018 & 596 & 2546 & 3142 & 2151 & 31.54 & 18.46 & 2.64 \\
\hline 2019 & 589 & 2590 & 3179 & 2180 & 31.42 & 18.65 & 1.05 \\
\hline
\end{tabular}

Note: ${ }^{1}$ Data corresponding to deaths within $24 \mathrm{~h}$ after the crash.

Figure 3 shows the comparison from 2000 to 2019 in Ecuador according to the sex of those dead in traffic accidents (annually).

female: 0 Joinpoints versus male: 0 Joinpoints

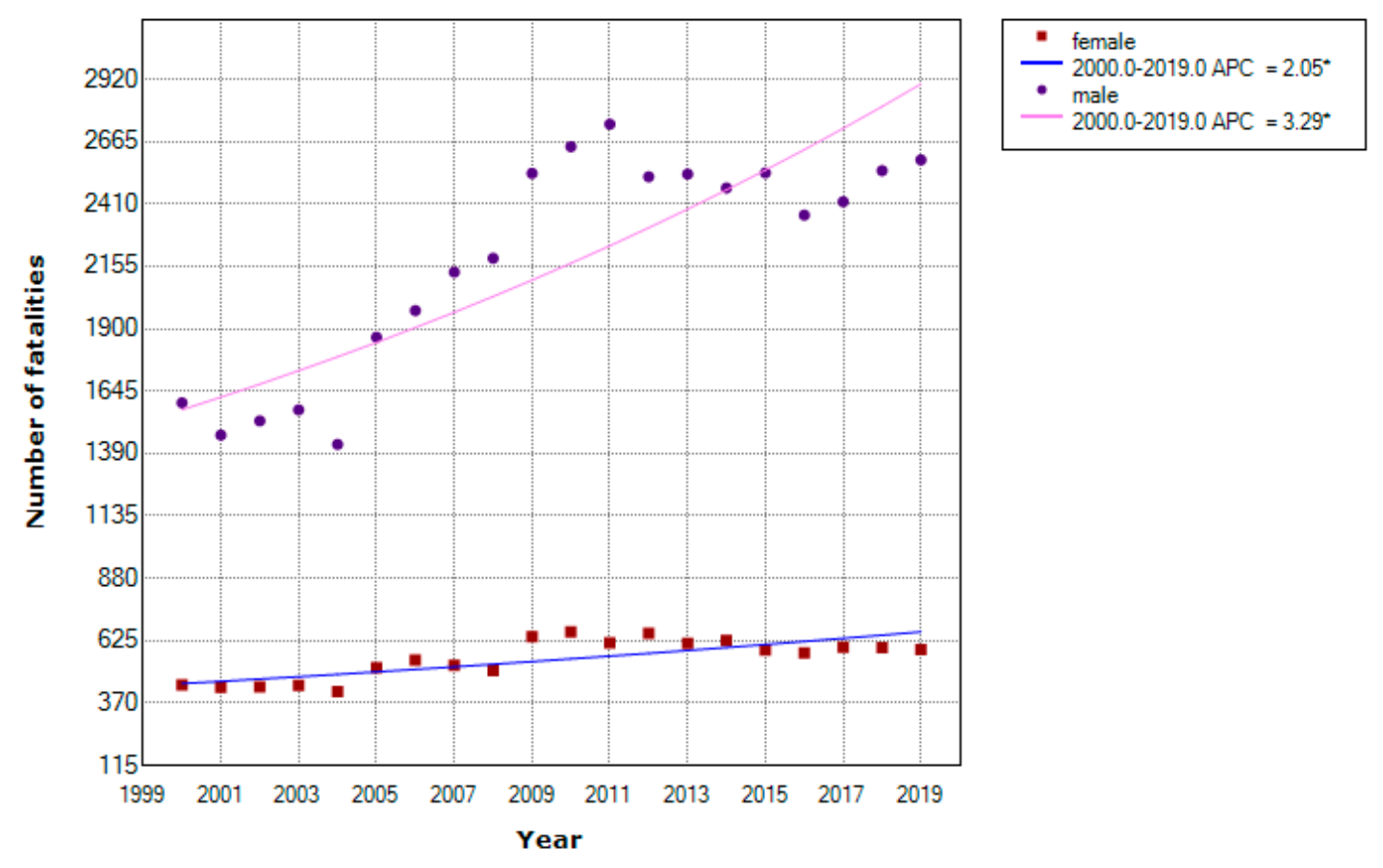

* Indicates that the Annual Percent Change (APC) is significantly different from zero at the alpha $=0.05$ level. Final Selected Model: female - 1 Joinpoint, male - 2 Joinpoints. Rejected Parallelism.

Figure 3. Comparison analysis of the number of fatalities in traffic crashes of male and female. 
In the Joinpoint analysis, the most significant changes were identified in the number of deaths according to sex (per year), as shown in Figure 3, with females presenting an increase of 2.05 per year (95\% CI: 1.2 to 2.9$)$ and males increasing by 3.29 per year $(95 \% \mathrm{CI}$ : 2.3 to 4.3 ). In the comparability test, the number of deaths (males and females) due to traffic accidents was not parallel (the selected model rejected parallelism, $p=0.0004$ ). There are international studies that conclude that females are involved in fewer traffic accidents $[23,26,31,34]$. Underlying these numbers are socioeconomic factors determining a higher number of males in the driver census. The late incorporation of females into the labor market, family characteristics, and other cultural barriers determines this configuration of driver censuses in large regions worldwide. For a rigorous comparison, it is necessary to have a measure of risk exposure, which is the mainstay of accident studies and, at the same time, one of the costliest variables to obtain (surveys, naturalistic studies, among others) from large sectors of the population to ensure its representativeness. Around the world, researchers are working on alternative means of elicitation, exploring new data sources, and in the Quasi-Induced Exposure (QIE) methodology, from data contained in accident databases. In the paper [81], they have developed a methodology for improving driver crash liability useful for the QIE approach. In addition, in research papers, it can be found that the age is a factor to be taken into account. In this paper, the methodology of contrast of proportions is developed to analyze the statistically significant differences in the severity of male and female drivers, according to age intervals, as the available and disaggregated data allow it (2017-2018). The analysis of the results can be found in Section 4.2.

Table 9 shows the age range of fatalities involved in traffic accidents registered in the period 2008-2019 in Ecuador.

Table 9. Age of fatalities due to traffic crashes during the period 2008 to 2019 in Ecuador (annual data).

\begin{tabular}{|c|c|c|c|c|c|c|c|c|c|c|}
\hline \multicolumn{11}{|c|}{ Ages Range } \\
\hline Year & $<1$ & 1-9 & $10-19$ & $20-29$ & $30-39$ & $40-49$ & $50-59$ & $60-69$ & $>699$ & $\begin{array}{c}\text { No } \\
\text { Information }\end{array}$ \\
\hline 2008 & 6 & 168 & 316 & 685 & 478 & 372 & 226 & 193 & 244 & 3 \\
\hline 2009 & 21 & 230 & 369 & 797 & 556 & 389 & 287 & 236 & 287 & 4 \\
\hline 2010 & 11 & 213 & 356 & 809 & 546 & 433 & 356 & 251 & 318 & 11 \\
\hline 2011 & 20 & 224 & 349 & 884 & 590 & 435 & 292 & 215 & 335 & 7 \\
\hline 2012 & 15 & 205 & 355 & 811 & 573 & 384 & 308 & 217 & 304 & 4 \\
\hline 2013 & 14 & 172 & 342 & 856 & 574 & 368 & 314 & 208 & 292 & 6 \\
\hline 2014 & 13 & 158 & 312 & 827 & 554 & 378 & 313 & 222 & 324 & 0 \\
\hline 2015 & 16 & 162 & 339 & 845 & 554 & 392 & 285 & 193 & 335 & 2 \\
\hline 2016 & 16 & 155 & 264 & 740 & 531 & 401 & 279 & 236 & 315 & 1 \\
\hline 2017 & 11 & 130 & 293 & 830 & 542 & 366 & 298 & 213 & 334 & 0 \\
\hline 2018 & 12 & 125 & 311 & 862 & 588 & 380 & 321 & 228 & 313 & 2 \\
\hline 2019 & 16 & 127 & 264 & 926 & 579 & 409 & 311 & 224 & 320 & 3 \\
\hline
\end{tabular}

From Table 9, it is noteworthy that of those killed in road traffic accidents $26.44 \%$ belong to the age range of 20-29 years ( $p=0.03)$, followed by the group of $30-39$ years $(17.85 \%)$ $(p=0.01), 40-49$ years $(12.60 \%)(p=0.04)$, over 69 years $(9.96 \%)(p=0.03), 50-59$ years $(9.61 \%)(p=0.01)$, and $1-9$ years $(5.54 \%)(p=0.01)$. The study conducted in Jharkhand (Republic of India) and those conducted by WHO, PAHO, and OISEVI coincide with the age range of the highest number of road traffic fatalities, which is 20-29 years [1,3,20,75], but unlike the work conducted in Ghana [21], the results are different, with the most vulnerable road users being children under ten years of age and the elderly.

Figure 4 shows the comparison analysis obtained from 2000 to 2019 in Ecuador, according to the age of those killed (annually) in traffic accidents. 
0 and 39 years: 0 Joinpoints versus 40 years and more: 0 Joinpoints
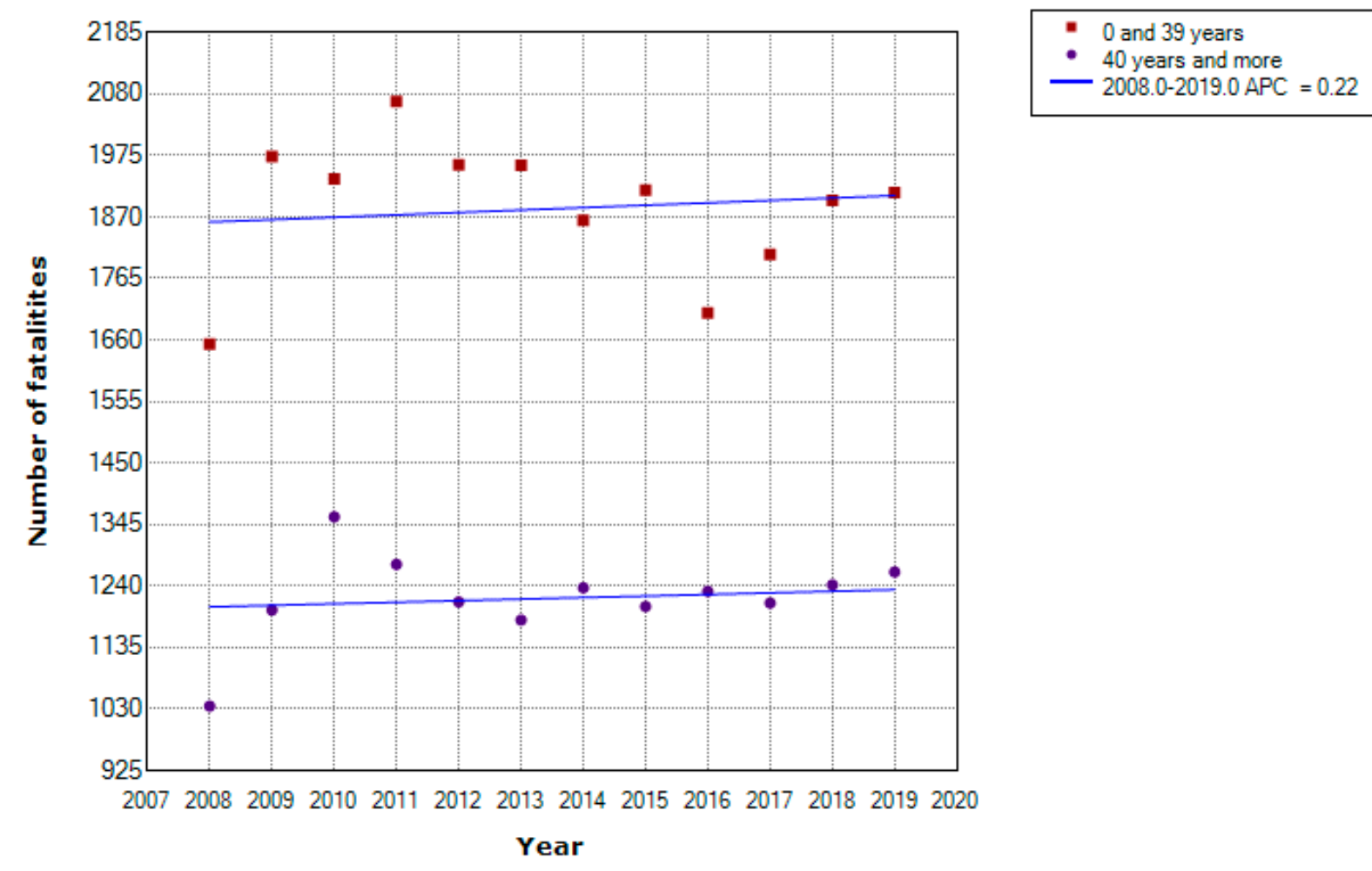

- Indicates that the Annual Percent Change (APC) is significantly different from zero at the alpha $=0.05$ level.

Final Selected Model: 0 and 39 years - 2 Joinpoints, 40 years and more - 2 Joinpoints. Failed to reject Parallelism.

Figure 4. Comparison analysis of deaths occurring in ages 0-39 years and 40 years and older.

Two age groups were analyzed by the comparison method, as shown in Figure 4, where the result was parallel $(p=0.137)$, and the number of deceased persons in both ages ranges from 0 to 39 years and 40 years and older increased by 0.22 per year (95\% CI: -0.6 to 1.0 ).

\subsection{Hypothesis Tests Results}

We want to analyze the sample data to either not reject the hypothesis of equal proportions of a given characteristic of the feature of two populations or to do so if the differences between the sample proportions are too larger, considering the statistical $(d)$ value (defined in Section 3.4) to accept or reject the hypothesis test.

In Table 10, the number of injured drivers in accidents traffic in Ecuador in the period 2017-2018 segregated by injury level according to the sex and age group is shown. The figures agreed with it is known: if absolute numbers are analyzed, there are more injured males than females, in all the levels of injury and each age group. It is important to keep in mind that the exposure is different between them, and as mentioned above, the exposure is not simple or directly available. To solve the problem, the risk comparison is made using the contrast proportions methodology to determine if there are significant differences in the proportion by injury level by sex and age intervals. The proportions are computed concerning the total of males or females, respectively, and we analyze if the differences between the sample proportions, as obtained from the data, are too large to accept in the statistical terminology, not to reject it. The results of the contrast are in Table 11. 
Table 10. Data of the injury of the driver according to the sex and age group in the period 2017-2018.

\begin{tabular}{cccccc}
\hline Sex & Age Group & Deceased & Injury & No-Injury & Unknown \\
\hline \multirow{5}{*}{ Male (M) } & 18 to 30 & 494 & 3.842 & 1931 & 6 \\
& 31 to 55 & 449 & 3400 & 3265 & 7 \\
& 56 to 75 & 90 & 587 & 804 & 1 \\
& $>76$ & 20 & 117 & 148 & 4 \\
& Global & 1053 & 7946 & 6148 & 18 \\
\hline \multirow{5}{*}{ Female (F) } & De 18 a 30 & 13 & 316 & 159 & 0 \\
& De 31 a 55 & 12 & 411 & 327 & 0 \\
& De 56 a 75 & 4 & 48 & 40 & 0 \\
& $>76$ & 0 & 5 & 4 & 0 \\
\hline
\end{tabular}

Table 11. Hypothesis tests of the driver' injury by sex and age group in the period 2017-2018.

\begin{tabular}{|c|c|c|c|c|c|c|c|}
\hline $\begin{array}{c}\text { Severity of } \\
\text { Driver }\end{array}$ & $\begin{array}{l}\text { Age } \\
\text { Group }\end{array}$ & Sex & CI. Low & CI: Up & Mean & Normal St. & Ratio $\mathrm{M} / \mathrm{F}$ \\
\hline \multirow{10}{*}{ Deceased } & \multirow[b]{2}{*}{18 to 30} & $\mathrm{M}$ & 0.0719 & 0.0856 & 0.0787 & \multirow[b]{2}{*}{1.65} & \multirow[b]{2}{*}{2.96} \\
\hline & & $\mathrm{F}$ & 0.0121 & 0.0412 & 0.0266 & & \\
\hline & \multirow{2}{*}{31 to 55} & $\mathrm{M}$ & 0.0573 & 0.0688 & 0.0631 & \multirow{2}{*}{8.82} & \multirow{2}{*}{3.94} \\
\hline & & $\mathrm{F}$ & 0.0068 & 0.0252 & 0.0160 & & \\
\hline & \multirow{2}{*}{56 to 75} & $\mathrm{M}$ & 0.0483 & 0.0731 & 0.0607 & \multirow{2}{*}{1.8} & \multirow{2}{*}{1.40} \\
\hline & & $\mathrm{F}$ & 0.0010 & 0.0860 & 0.0435 & & \\
\hline & \multirow{2}{*}{$>76$} & $\mathrm{M}$ & 0.0393 & 0.0991 & 0.0692 & \multirow{2}{*}{ - } & \multirow{2}{*}{ - } \\
\hline & & $\mathrm{F}$ & 0.0000 & 0.0000 & 0.0000 & & \\
\hline & \multirow{2}{*}{ Global } & $M$ & 0.0653 & 0.0736 & 0.0694 & \multirow{2}{*}{9.03} & \multirow{2}{*}{3.21} \\
\hline & & $\mathrm{F}$ & 0.0137 & 0.0296 & 0.0217 & & \\
\hline \multirow{10}{*}{ Injury } & \multirow{2}{*}{18 to 30} & $\mathrm{M}$ & 0.6002 & 0.6248 & 0.6125 & \multirow{2}{*}{-0.23} & \multirow{2}{*}{$0.95(1.05)$} \\
\hline & & $\mathrm{F}$ & 0.6043 & 0.6908 & 0.6475 & & \\
\hline & \multirow{2}{*}{31 to 55} & $\mathrm{M}$ & 0.4656 & 0.4893 & 0.4770 & \multirow{2}{*}{-2.55} & \multirow{2}{*}{$0.87(1.15)$} \\
\hline & & $\mathrm{F}$ & 0.5117 & 0.5843 & 0.5480 & & \\
\hline & \multirow{2}{*}{56 to 75} & M & 0.377 & 0.4215 & 0.3961 & \multirow{2}{*}{-3.87} & \multirow{2}{*}{$0.76(1.32)$} \\
\hline & & $\mathrm{F}$ & 0.4176 & 0.6259 & 0.5217 & & \\
\hline & \multirow{2}{*}{$>76$} & $\mathrm{M}$ & 0.3471 & 0.4626 & 0.4048 & \multirow{2}{*}{0.00} & \multirow[b]{2}{*}{0.73} \\
\hline & & $\mathrm{F}$ & 0.2243 & 0.8869 & 0.5556 & & \\
\hline & \multirow{2}{*}{ Global } & $\mathrm{M}$ & 0.5159 & 0.5321 & 0.5240 & \multirow{2}{*}{-2.39} & \multirow{2}{*}{$1.10(0.90)$} \\
\hline & & $\mathrm{F}$ & 0.5556 & 0.6095 & 0.5825 & & \\
\hline
\end{tabular}

Note: The inverse ratio is indicated in parentheses (ratio $\mathrm{F} / \mathrm{M}$ ).

The existence of significant differences is measured by the 95\% threshold for the normal statistic which is 2 . In Table 11, the mean value and Low and Up CI are shown beside the normal statistic of the hypothesis test contrast, besides the ratio between the proportions.

In road collisions in Ecuador of the period analyzed, there exist significant sex differences for injured levels regarding the age group. In the case of deceased level, the risk is different by gender in the 31-55 years age group, and the differences decrease to be not significant for more younger and senior drivers by gender. The ratio between the proportions in Table 11 is $\mathrm{M} / \mathrm{F}=2.96$ from 18 to $30,3.94$ from 31 to 55 , and 1.40 in the interval of $56-75$ years.

In the injury level, the contrast of the hypothesis test allows one to conclude that there is more risk to be injured within the sample of female drivers, and there are significant differences with males in two age groups encompassing from 31 to 75 years. The ratios indicate a larger proportion of females in these intervals ( 1.15 and 1.32, respectively). 
This analysis remarks the importance of ratios analysis, instead of absolute numbers, showing that conclusions can differ depending on gender and age.

\subsection{Limitation of the Study}

This study used the information on traffic accidents, available annually from INEC; in which, there was no disaggregation of variables, for example, types of collisions, road users, and did not record light and serious injuries as of 2015. From 2019, the data improved, but they are still unreliable.

The availability of disaggregated information for drivers in two years (2017-2018) made it possible to apply the contrast of hypotheses, leading to conclusions with significant nuances.

\section{Conclusions}

We conclude that from 2000 to 2014, the decrease in traffic collisions has not been constant; there are years when they increase. In addition, the number of deaths has increased in most years, making road safety a public health issue for Ecuador. The analysis of the results indicates that since the new traffic law came into force in Ecuador at the end of 2014, there has been a $31.12 \%$ decrease in the number of traffic accidents up to 2019 . Despite this decrease, traffic fatalities show a worrying growth rate of $1.8 \%$, and if this trend continues, Ecuador has not met the target 3.6 of the SDG 2020 and has to adopt its measures to comply with the new decade on road safety until 2030.

The analysis revealed that $41.76 \%$ of traffic accidents in Ecuador are caused by recklessness and carelessness of drivers, such as: driving inattentive to traffic conditions, driving while drowsy or in poor physical condition, and not keeping the minimum lateral safety distance between vehicles, which, in general, are risky behaviors on the road. In addition, the type of traffic accident with the highest incidence is a collision with an average of $45.29 \%$. From 2015 to 2019 , the automobile has a higher probability of collision with $35.74 \%$, and motorcycles have a lower probability of collision with $16.55 \%$. The predominant time of traffic collisions recorded from 2015 to 2019 arises in the afternoon hours between 12: 00 and $17: 59$ with $29.75 \%$.

The analysis by sex shows that men are more likely to die in traffic accidents, with an average of approximately $2182(80 \%)$ deaths, and women $551(20 \%)$ deaths in the period studied, the most affected age range is between 20 and 29 years of age, followed by those between 30 and 39 years of age. From these data, it is not known whether the victims correspond to pedestrians, drivers, cyclists, and other road users, because it is not recorded by those responsible for road safety.

The hypothesis test analysis remarks the importance of considering ratios instead of absolute numbers, showing significant differences between males and females, depending on the age group and level of injury. In the case of deceased level, the risk is different for males and females in the 31-55 years age group, and the differences decrease to be not significant for more younger and senior drivers of both sexes. The ratio between the proportions in Table 11 is $\mathrm{M} / \mathrm{F}=2.96$ from 18 to 30, 3.94 from 31 to 55, and 1.40 in the interval of 56-75 years.

For the injury level, the hypothesis test contrast allows one to conclude that there is a higher risk of being injured within the sample of female than men drivers, and there are significant differences between them in two age groups: from 31 to 75 years old. The ratios indicate a higher proportion of females in these intervals (1.15 and 1.32, respectively).

Finally, the data analysis remarks the recording process must be improved; this would contribute to aid future research to learn about the worried health problem and the influencing factors and would propose more concrete solutions to reduce traffic crashes in Ecuador. 
Author Contributions: This manuscript is an original work that has not been previously published and has not currently been considered for another journal. The authors' responsibilities were as follows: Conceptualization, F.E.E.-M., B.A.-R., and F.A.-I.; methodology, F.E.E.-M. and B.A.-R.; software, C.F.O.-R., H.D.Z.-P., G.P.-Q., and B.A.-R.; validation, G.P.-Q. and B.A.-R.; formal analysis, F.E.E.-M., B.A.-R., and F.A.-I.; data curation, C.F.O.-R., H.D.Z.-P., and G.P.-Q.; research, F.E.E.-M., C.F.O.-R., H.D.Z.-P., G.P.-Q., and F.A.-I.; writing: original draft preparation, F.E.E.-M., B.A.-R., F.A.I., C.F.O.-R., and H.D.Z.-P.; writing-review and editing, F.E.E.-M., B.A.-R., F.A.-I., and G.P.-Q.; visualization, C.F.O.-R., H.D.Z.-P., and G.P.-Q.; project management, F.E.E.-M.; resources, F.E.E.-M.; All authors have read and agreed to the published version of the manuscript.

Funding: This research did not receive any specific grant from funding agencies in the public, commercial, or not-for-profit sectors.

Institutional Review Board Statement: Not applicable.

Informed Consent Statement: Not applicable.

Data Availability Statement: The data presented in this article is provided by INEC and ANT.

Acknowledgments: The authors would like to thank the Grupo de Investigación en Ingeniería del Transporte (GIIT) of the Universidad Politécnica Salesiana (UPS), Cuenca, Ecuador and the Instituto Universitario de Investigación del Automóvil Francisco Aparicio Izquierdo (INSIA), Universidad Politécnica de Madrid (UPM), Madrid, Spain. For the institutional support to the development of cooperative work under FA.-I. supervision and through the participation of researchers and doctoral students such as B.A.-R. and G.P.-Q., F.E.E.-M.

Conflicts of Interest: The authors declare they have no conflict of interest.

\section{References}

1. World Health Organization. Global Status Report on Road Safety 2018; WHO: Geneva, Sweitzerland, 2018 ; ISBN 9789241565684.

2. United Nations. Global Plan for the Decade of Action for Road Safety 2011-2020; United Nations: Geneva, Switzerland, 2010.

3. Pan American Health Organization. Status of Road Safety in the Region of the Americas; OPS: Washington, DC, USA, 2019; ISBN 978-92-75-12086-6.

4. Poswayo, A.; Kalolo, S.; Rabonovitz, K.; Witte, J.; Guerrero, A. School Area Road Safety Assessment and Improvements (SARSAI) programme reduces road traffic injuries among children in Tanzania. Inj. Prev. 2018, 25, 414-420. [CrossRef]

5. World Bank. Guide for Road Safety Opportunities and Challenges; World Bank: Washington, DC, USA, 2020.

6. Ministerio de Transportes y Obras Públicas. VII Semana de Seguridad Vial; 2016. Available online: https://www.obraspublicas.gob. ec/mtop-inaugurara-la-vii-semana-de-seguridad-vial-2016/ (accessed on 10 May 2020).

7. Asamblea Nacional del Ecuador. Ley Organica de Transporte Terrestre Transito y Seguridad Vial; Asamblea Nacional del Ecuador: Quito, Ecuador, 2014.

8. Tapia Claudio, Ó.M.; Suasnavas Bermúdez, P.R.; Campos, Y. Accidentes de Tránsito en Ecuador 2016-2017 Accidentalidad-MorbilidadMortalidad; Universidad Internacional SEK: Quito, Ecuador, 2017; ISBN 978-9942-36-811-9.

9. Gómez García, A.R.; Ayala Heredia, M.; Campos Villalta, Y.Y. Characterization of 1967 cases of deaths by traffic accidents in Ecuador. Espirales Rev. Multidiscip. Investig. 2018, 2, 57-68.

10. Peden, M.M.; Puvanachandra, P. Looking back on 10 years of global road safety. Int. Health 2019, 11, 327-330. [CrossRef]

11. United Nations. Impoving Globar Road Safety; United Nations: New York, NY, USA, 2020.

12. Nogueira Monteiro, N.; da Silva Tavares, R.; Monteiro da Hora, H.R.; Sobral Barcellos, R.G. Brazilian federal roads: Identifying patterns in traffic accidents using data mining techniques with apriori algorithm. In Proceedings of the XXIII Encontro Nacional de Modelagem Computacional; Universidade Federal To Tocantins: Palmas, Brasil, 2020.

13. Măirean, C.; Havârneanu, C.E. The relationship between drivers' illusion of superiority, aggressive driving, and self-reported risky driving behaviors. Transp. Res. Part F Traffic Psychol. Behav. 2018, 55, 167-174. [CrossRef]

14. Tao, D.; Zhang, R.; Qu, X. The role of personality traits and driving experience in self-reported risky driving behaviors and accident risk among Chinese drivers. Accid. Anal. Prev. 2017, 99, 228-235. [CrossRef]

15. Barrera-Sánchez, E.; Pazmiño-Maji, R. Determination of the main causes of transit accidents in Ecuador since 2016 Until 2018. KnE Eng. 2020, 2020, 514-525.

16. Blazquez, C.A.; Salazar, L. Spatio-temporal Analysis of Public Transit Crashes in Viña del Mar and Valparaíso, Chile. Available online: https:/ / researchers.unab.cl/en/publications/spatio-temporal-analysis-of-public-transit-crashes-in-vi\%C3\%B1a-del-ma (accessed on 10 May 2020).

17. Asare, I.O.; Mensah, A.C. Crash severity modelling using ordinal logistic regression approach. Int. J. Inj. Contr. Saf. Promot. 2020, 27, 412-419. [CrossRef] [PubMed] 
18. Araújo de Sousa, R.; Meneses de Sá Sousa, C.; Soares e Silva, F.R.; Pacheco Rodrigues, M.T.; de Oliveira Cardoso, O.; Medeiros Mascarenhas, M.D. Transport accident mortality time trend and spatial distribution in Piauí, Brazil, 2000-2017. Epidemiol. e Serv. saude Rev. do Sist. Unico Saude do Bras. 2020, 29, e2019558.

19. Oster, C.V.; Strong, J.S. Analyzing road safety in the United States. Res. Transp. Econ. 2013, 43, 98-111. [CrossRef]

20. Gupta, G.; Rani, S.; Kumar, R.; Priyedarshi, P.; Singh, B. Incidence and pattern of road traffic injuries in tribal population of Jharkhand: One-year study in a tertiary care teaching hospital. J. Fam. Med. Prim. Care 2020, 9, 5223.

21. Damsere-Derry, J.; Palk, G.; King, M. Road accident fatality risks for "vulnerable" versus "protected" road users in northern Ghana. Traffic Inj. Prev. 2017, 18, 736-743. [CrossRef]

22. Constantinou, E.; Panayiotou, G.; Konstantinou, N.; Loutsiou-Ladd, A.; Kapardis, A. Risky and aggressive driving in young adults: Personality matters. Accid. Anal. Prev. 2011, 43, 1323-1331. [CrossRef]

23. Al-Balbissi, A.H. Role of gender in road accidents. Traffic Inj. Prev. 2003, 4, 64-73. [CrossRef]

24. Turner, C.; McClure, R. Age and gender differences in risk-taking behaviour as an explanation for high incidence of motor vehicle crashes as a driver in young males. Inj. Control Saf. Promot. 2003, 10, 123-130. [CrossRef]

25. Jiménez-Moleón, J.J.; Lardelli-Claret, P.; Luna-del-Castillo, J.d.D.; García-Martín, M.; Bueno-Cavanillas, A.; Gálvez-Vargas, R. Efecto de la edad, el sexo y la experiencia de los conductores de 18 a 24 años sobre el riesgo de provocar colisiones entre turismos. Gac. Sanit. 2004, 18, 166-176. [CrossRef] [PubMed]

26. D'Ambrosio, L.A.; Donorfio, L.K.M.; Coughlin, J.F.; Mohyde, M.; Meyer, J. Gender differences in self-regulation patterns and attitudes toward driving among older adults. J. Women Aging 2008, 20, 265-282. [CrossRef] [PubMed]

27. Durán Segura, M.; Cantón Cortés, D.; Castro Ramírez, C. Changing patterns in women's driving. Int. J. Psychol. Res. 2009, 2, 54-66. [CrossRef]

28. Bose, D.; Segui-Gomez, M.; Crandall, J.R. Vulnerability of female drivers involved in motor vehicle crashes: An analysis of US population at risk. Am. J. Public Health 2011, 101, 2368-2373. [CrossRef]

29. Laapotti, S.; Keskinen, E.; Rajalin, S. Comparison of young male and female drivers' attitude and self-reported traffic behaviour in Finland in 1978 and 2001. J. Saf. Res. 2003, 34, 579-587. [CrossRef]

30. Williams, A.F. Teenage drivers: Patterns of risk. J. Saf. Res. 2003, 34, 5-15. [CrossRef]

31. Harris, C.R.; Jenkins, M.; Glaser, D. Gender differences in risk assessment: Why do women take fewer risks than men?-PsycNET. Am. Psychol. Assoc. 2006, 1, 48-63.

32. Claret, P.L.; Del Castillo, J.d.D.L.; Moleón, J.J.J.; Cavanillas, A.B.; Martín, M.G.; Vargas, R.G. Age and sex differences in the risk of causing vehicle collisions in Spain, 1990 to 1999. Accid. Anal. Prev. 2003, 35, 261-272. [CrossRef]

33. Özkan, T.; Lajunen, T. What causes the differences in driving between young men and women? The effects of gender roles and sex on young drivers' driving behaviour and self-assessment of skills. Transp. Res. Part F Traffic Psychol. Behav. 2006, 9, 269-277. [CrossRef]

34. Massie, D.L.; Campbell, K.L.; Williams, A.F. Traffic Accident involvement rates by driver age and gender. Accid. Anal. Prev. 1995, 27, 73-87. [CrossRef]

35. Chandraratna, S.; Stamatiadis, N. Quasi-induced exposure method: Evaluation of not-at-fault assumption. Accid. Anal. Prev. 2009, 41, 308-313. [CrossRef] [PubMed]

36. Méndez, Á.G.; Izquierdo, F.A. Quasi-induced exposure: The choice of exposure metrics. Accid. Anal. Prev. 2010, 42, 582-588. [CrossRef]

37. Lardelli-Claret, P.; Luna-Del-Castillo, J.D.D.; Jiménez-Mejías, E.; Pulido-Manzanero, J.; Barrio-Anta, G.; García-Martín, M.; Jiménez-Moleón, J.J. Comparison of two methods to assess the effect of age and sex on the risk of car crashes. Accid. Anal. Prev. 2011, 43, 1555-1561. [CrossRef]

38. Jiang, X.; Lyles, R.W.; Guo, R. A comprehensive review on the quasi-induced exposure technique. Accid. Anal. Prev. 2014, 65, 36-46. [CrossRef]

39. Sanjurjo-De-No, A.; Arenas-Ramírez, B.; Mira, J.; Aparicio-Izquierdo, F. Driver pattern identification in road crashes in spain. IEEE Access 2020, 8, 182014-182025. [CrossRef]

40. TosiI, J.; TrógoloII, M.; Ledesma, R.D. Attitudes and Risky Driving Behaviors. Psicol. Am. Lat. 2019, 31, 39-52. Available online: http:/ / pepsic.bvsalud.org/scielo.php?script=sci_abstract\&pid=S1870-350X2019000100005\&lng=pt\&nrm=iso\&tlng=en (accessed on 5 May 2020).

41. Chaves Pabón, S.B.; Arias Rojas, W. Análisis de las fatalidades por accidentes de tránsito en Colombia acontecidos en el periodo 2011-2015. Redes Ing. 2017, 8, 226-239.

42. Congacha, A.E.; Barba Brito, J.; Pacheco, L.P.; Delgado, J. Characterization of traffic accidents in Ecuador. NOVASINERGIA Rev. Digit. CIENCIA Ing. Y Tecnol. 2019, 2, 17-29.

43. Espinoza Molina, F.E.; Arenas Ramirez, B.D.V.; Aparicio Izquierdo, F.; Zúñiga Ortega, D.C. Road safety perception questionnaire (RSPQ) in Latin America: A development and validation study. Int. J. Environ. Res. Public Health 2021, 18, 2433. [CrossRef]

44. Bhatti, J.A.; Salmi, L.R.; Lagarde, E.; Razzak, J.A. Concordance between road mortality indicators in high-income and low- and middle-income countries. Traffic Inj. Prev. 2010, 11, 173-177. [CrossRef] [PubMed]

45. Yamamoto, T.; Hashiji, J.; Shankar, V.N. Underreporting in traffic accident data, bias in parameters and the structure of injury severity models. Accid. Anal. Prev. 2008, 40, 1320-1329. [CrossRef] [PubMed] 
46. World Health Organization; Foundation for the Automobile and Society; Global Road Safety Partnership; World Bank. Data systems: A Road Safety Manual for Decision-Makers and Practitioners I Asia and Pacific Road Safety Observatory (APRSO); WHO: Geneva, Switzerland, 2010.

47. Guimarães, A.G.; da Silva, A.R. Impact of regulations to control alcohol consumption by drivers: An assessment of reduction in fatal traffic accident numbers in the Federal District, Brazil. Accid. Anal. Prev. 2019, 127, 110-117. [CrossRef]

48. Heydari, S.; Hickford, A.; Mcllroy, R.; Turner, J.; Bachani, A.M. Road safety in low-income countries: State of knowledge and future directions. Sustainability 2019, 11, 6249. [CrossRef]

49. Hyder, A.A.; Paichadze, N.; Toroyan, T.; Peden, M.M. Monitoring the Decade of Action for Global Road Safety 2011-2020: An update. Glob. Public Health 2017, 12, 1492-1505. [CrossRef]

50. Toroyan, T. Global status report on road safety. Inj. Prev. 2009, 15, 286. [CrossRef]

51. Agencia Nacional de Tránsito. Estadísticas de transporte terrestre y seguridad vial. Available online: https://www.ant.gob.ec/ index.php/estadisticas (accessed on 5 May 2020).

52. International Transport Forum. Benchmarking Sobre Seguridad Vial: Enfoque Metodológico; OECD: Paris, France, 2016.

53. Instituto Nacional de Estadísticas y Censos. Nacimientos y Defunciones-información histórica. Available online: https: / / www.ecuadorencifras.gob.ec/nacimientos-y-defunciones-informacion-historica/ (accessed on 10 July 2020).

54. National Institutes of Health. Download Joinpoint desktop software. Available online: https://surveillance.cancer.gov/joinpoint/ download (accessed on 5 August 2020).

55. Ahmed, I.U.; Gaweesh, S.M.; Ahmed, M.M. Exploration of hazardous material truck crashes onwyoming's interstate roads using a novel hamiltonian monte carlo markov chain bayesian inference. Transp. Res. Rec. 2020, 2674, 661-675. [CrossRef]

56. Kim, H.-J.; Fay, M.P.; Feuer, E.J.; Midthune, D.N. Permutation tests for joinpoint regression with applications to cancer rates. Stat. Med. 2000, 19, 335-351. [CrossRef]

57. Peláez Valencia, M.A. Modelo de Cuantificación Económica Para Implementación de Sistemas Inteligentes de Transporte (ITS) en Medellín; Universidad Nacional de Colombia: Medellin, Colombia, 2016.

58. Lerman, P.M. Fitting segmented regression models by grid search. Appl. Stat. 1980, 29, 77. [CrossRef]

59. Jovic Vranes, A.; Bjegovic Mikanovic, V.; Milin Lazovic, J.; Kosanovic, V. Road traffic safety as a public health problem: Evidence from Serbia. J. Transp. Health 2018, 8, 55-62. [CrossRef]

60. Weisbrot, P.M.; Johnston, J.; Merling, L. Mark Weisbrot es Codirector del CEPR Una Década de Reformas: Politicas Macroeconómicas y Cambios Institucionales en Ecuador y Sus Resultados; CEPR: Washington, DC, USA, 2017.

61. Banco Central del Ecuador. La Economia Ecuatoriana Luego de 10 Años de Dolarizacion; BCE: Quito, Ecuador, 2010.

62. Wiebe, D.J.; Ray, S.; Maswabi, T.; Kgathi, C.; Branas, C.C. Développement économique et décès occasionnés par les accidents de la route dans deux pays africains voisins. Afr. J. Emerg. Med. 2016, 6, 80-86. [CrossRef] [PubMed]

63. Bishai, D.; Quresh, A.; James, P.; Ghaffar, A. National road casualties and economic development. Health Econ. 2006, 15, 65-81. [CrossRef] [PubMed]

64. Torres Flores, J.A. Metodología de Evaluación de la Seguridad Vial en Intersecciones Basada en el Análisis Cuantitativo de Conflictos Entre Vehículos. Ph.D. Thesis, Universidad Politécnica de Madrid, Madrid, Spanish, 2012.

65. Instituto Nacional de Estadísticas y Censos. Anuario de Estadísticas de Transporte. Available online: https://www. ecuadorencifras.gob.ec/documentos/web-inec/Estadisticas_Economicas/EstadisticadeTransporte/2019/2019_ANET_PPT. pdf (accessed on 6 May 2020).

66. Sierra, J.C. Estimating road transport fuel consumption in Ecuador. Energy Policy 2016, 92, 359-368. [CrossRef]

67. ANT. Reglamento General Para la Aplicación de la Ley Orgánica de Transporte Terrestre, Tránsito y Seguridad Vial; ANT: 2016. Available online: http:/ / www.vertic.org/media/National\%20Legislation/Ecuador/EC_Regalmento_Ley_Organica_Transporte.pdf (accessed on 6 May 2020).

68. Ministerio de Transporte y Obras Públicas. Inversión en infraestructura vial. Available online: https://www.obraspublicas.gob. ec/el-ministerio-de-transporte-y-obras-publicas-invirtio-725-millones-en-infraestructura-vial/ (accessed on 1 July 2021).

69. Calvo-Poyo, F.; Navarro-Moreno, J.; de Oña, J. Road investment and traffic safety: An international study. Sustainability 2020, $12,6332$. [CrossRef]

70. Sistema Oficial de Contratación Pública. Adquisición e Instalación de radares de velocidad informativos. Available online: https://www.compraspublicas.gob.ec/ProcesoContratacion/compras/PC/informacionProcesoContratacion2.cpe? idSoliCompra=gaObcF-xyJxOaWtRHmRPe7jGqfPhu0U_YtxpNLxP21U\&fbclid=IwAR1c8IAyQZ-X7FCl5WMOHIZtWb1 aVVyRiU5C9Bm0si5qt5rdOs4hG_ZLtlc (accessed on 2 July 2021).

71. Pillajo-Quijia, G.; Arenas-Ramírez, B.; González-Fernández, C.; Aparicio-Izquierdo, F. Influential Factors on Injury Severity for Drivers of Light Trucks and Vans with Machine Learning Methods. Sustainability 2020, 12, 1324. [CrossRef]

72. Asociación de Empresas Automotrices del Ecuador. Anuario 2019; AEADE: Quito, Ecuador, 2019.

73. Aparicio Izquierdo, F.; Arenas Ramírez, B.; Bernardos Rodríguez, E. The interurban DRAG-Spain model: The main factors of influence on road accidents in Spain. Res. Transp. Econ. 2013, 37, 57-65.

74. Asamblea Nacional del Ecuador. Reglamento a Ley Organica de Transporte Terrestre y Seguridad Vial; ANT: Quito, Ecuador, 2009.

75. Observatorio Iberoamericano de Seguridad Vial. VII Informe Iberoamericano de Seguridad Vial 2015-16; OISEVI: New York, NY, USA, 2017. Available online: https://issuu.com/buenaspracticasmotos/docs/oisevi_vii_informe_iberoamericano_d (accessed on 6 May 2020). 
76. Cantillo, V.; Márquez, L.; Díaz, C.J. An exploratory analysis of factors associated with traffic crashes severity in Cartagena, Colombia. Accid. Anal. Prev. 2020, 146, 105749. [CrossRef]

77. Torres-Quintero, A.; Palacios-Doncel, D.L.; Dominguez-Torres, M.T.; Gáfaro-Barrera, M.E.; Burbano-Valente, J. Masculinities at play. A sociocultural approach to the practices of risky riding among male motorcyclists in Valledupar, Colombia. J. Transp. Health 2019, 14, 100599. [CrossRef]

78. OECD/The World Bank. Health at a Glance: Latin America and the Caribbean 2020; OECD: París, Francia, 2020.

79. Passmore, J.; Yon, Y.; Mikkelsen, B. Progress in reducing road-traffic injuries in the WHO European region. Lancet Public Health 2019, 4. [CrossRef]

80. Furas, A.; Ramos, J.; Bhalla, K.; Garrido, N. Mejora de los Estándares de Seguridad de los Vehículos en América Latina y el Caribe a Través de la Adopción de Reglamentos ONU y Sistemas de Información al Consumidor: Informe Final Del Proyecto Bien Público Regional (BPR); Zamora, E., Ed.; IDB: Washington, DC, USA, 2019.

81. Sanjurjo-De-no, A.; Arenas-Ramírez, B.; Mira, J.; Aparicio-Izquierdo, F. Driver liability assessment in vehicle collisions in Spain. Int. J. Environ. Res. Public Health 2021, 18, 1475. [CrossRef] [PubMed] 